\title{
Immune Complexes and Visceral Deposits of Measles Antigens in Subacute Sclerosing Panencephalitis
}

\author{
A. D. DAYAN, MOLLIE I. STOKES
}

British Medical fournal, 1972, 2, 374-376

\section{Summary}

Immunofluorescence has been used to study visceral organs from a case of subacute sclerosing panencephalitis. Immune complexes were shown as granular deposits of IgG, complement, and measles antigens in renal glomeruli. Measles antigens were detected in the spleen, liver, and lymph nodes from many parts of the body.

Immune-complex formation may be important in the aetiology of this disease and perhaps in causing some of its tissue damage. The rarity of subacute sclerosing panencephalitis may be due to an unusual pattern of immunological reactivity required in a patient before a measles infection can produce a subacute encephalitis.

\section{Introduction}

Subacute sclerosing panencephalitis is a rare form of subacute or chronic infection of the nervous system by a measles-like virus. The evidence for this was only circumstantial at first (Connolly et al., 1968; Sever and Zeman, 1968) but a virus with many of the biological properties of measles has now been isolated from the brain in many of these cases (Horta-Barbosa et al., 1969; Payne et al., 1969).

The relationships between such a temperate viral infection and the patient's immune responses are largely unexplored in man, but a variety of immunological and other abnormalities have been suggested to account for this apparently unique form of chronic measles infection (Burnet, 1968; Dayan, 1971) and for some of the damage it causes in the brain (ter Meulen et al., 1969). In animals it has been shown that certain virus infections may lead to the production of circulating, pathogenic antigenantibody complexes- "immune complexes" (Notkins, 1971; Oldstone and Dixon, 1971).

It is possible that the ability to produce such complexes containing infectious virus may be important in establishing the chronic form of the virus infection.

A case of subacute sclerosing panencephalitis studied recently at necropsy was examined for exidence of immune-complex formation and to show the distribution of the aetiological agent.

\section{Materials and Methods}

At necropsy in the case described below samples were obtained from many systemic organs and viscera and from the brain and spinal cord. Thin slices of tissue were snap-frozen at $-70^{\circ} \mathrm{C}$ and stored at $-20^{\circ} \mathrm{C}$ until used. Cryostat sections were air dried on slides and washed for two hours in phosphate-buffered saline at room temperature before being prepared for examination by immunofluorescence. Both the direct single layer (fluorescein conjugates against immunoglobulin fractions and the $\beta_{1} c$ compcnent of complement) and the indirect double layer sandwich techniques (against measles antigens) were used. All

Department of Neuropathology, Institute of Neurology, Queen Square, London W.C.I

A. D. DAYAN, M.D., M.R.C.PATH., Consultant Neuropathologist

MOLLIE I. STOKES, F.I.M.I.T., Senior Technician the antisera were absorbed first with a human liver powder and had been shown not to stain fresh normal human tissues. The specificity of the deposits of immunoglobulin were checked by preliminary treatment of the sections with a non-fluorescent antihuman globulin.

\section{CASE REPORT}

The patient, an engineering apprentice, was well until the middle of 1969 when he was 19 years old. Over several months he developed changes in personality, impairment of thought, and myoclonus.

His condition became worse until he became almost decerebrate and died after an illness lasting two years. Throughout the illness the serum measles antibody titres were very high-for example, complement-fixing serum 2,048, C.S.F. 64; HAI-serum 128, C.S.F. 8. The C.S.F. colloidal gold curve was paretic and the IgG content was raised. The E.E.G. showed the repetitive complexes typical of this disease.

Necropsy was started within 30 minutes of death. The viscera, including organs of the reticuloendothelial system, appeared normal. On micropsy lymph nodes in the axillae, mediastinum, and abdomen mainly contained primary follicles, and those from the neck contained germinal centres; the peripheral sinuses contained lymphocytes, macrophages, and a few plasma cells but no multinucleate or giant cells. In the spleen Malpighian bodies were found, which appeared normal, and, in the red pulp, lymphocytes, macrophages, and some plasma cells. The thymus contained a cyst, and its parenchyma consisted of small lobules of lymphocytes and calcified Hassall's corpuscles inicrspersed with large amounts of fibrofatty tissue. No germinal centres were seen in it. No inclusion bodies were fcund in any of the viscera. The kidneys appeared normal and so did the lungs, liver, endocrine glands, and the intestinal tract and its associated lymphoid tissue.

The brain showed a diffuse subacute panencephalitis with a little perivascular cuffing by inflammatory cclls, patchy gliotic scarring in many areas of the grey and white matter, and occasional foci of macrophages around degenerating neurones. Sparse typical intranuclear inclusion bodies were found in neurones and glial cells.

\section{Results}

\section{IMMUNE COMPLEXES}

A convenient way of detecting immune complexes morphologically is to use immunofluorescence to show granular deposits of antigen, antibody, and complement in glomerular capillaries in thoroughly washed cryostat sections (Houba et al., 1970; Oldstone and Dixon, 1971).

In the kidneys of the present patient well-washed sections showed granular deposits of IgG in the capillaries of $10-15 \%$ of all glomeruli (Fig. 1). Very small amounts of IgM were seen occasionally; IgA was not detected. Complement $\left(\beta_{1} c\right)$ was also found in $10-15 \%$ of the glomeruli and was distributed in a similar fashion to IgG (Fig. 2).

Previous treatment of the sections with a non-fluorescent antihuman globulin serum completely prevented reaction with IgG and IgM antisera. Attempts were made to elute the bound antibody with $0.02 \mathrm{M}$ citrate buffer at pH 2.8 (Freedman and Markowitz, 1962) and with 3 M KCN (Dandliker et al., 1967). Although the intensity of fluorescence was diminished there was too much destruction of the architecture of the tissue for accurate observation. 
Bound antibodies and complement were not detected in any other organ except the brain. Immunofluorescent examination of kidney tissue obtained shortly after death from other patients who did not have encephalitis did not show any deposits of immunoglobulin or complement; nor was there any staining when sections of various tissues from control patients were treated with the present patient's serum and fluoresceinconjugated antihuman IgG or IgM.

\section{IMMUNOGLOBULIN PRODUCTION}

Moderate numbers of IgG-containing cells and smaller numbers of IgM-containing cells were seen in the peripheral sinuses of cervical, axillary, and mediastinal lymph nodes and many fewer

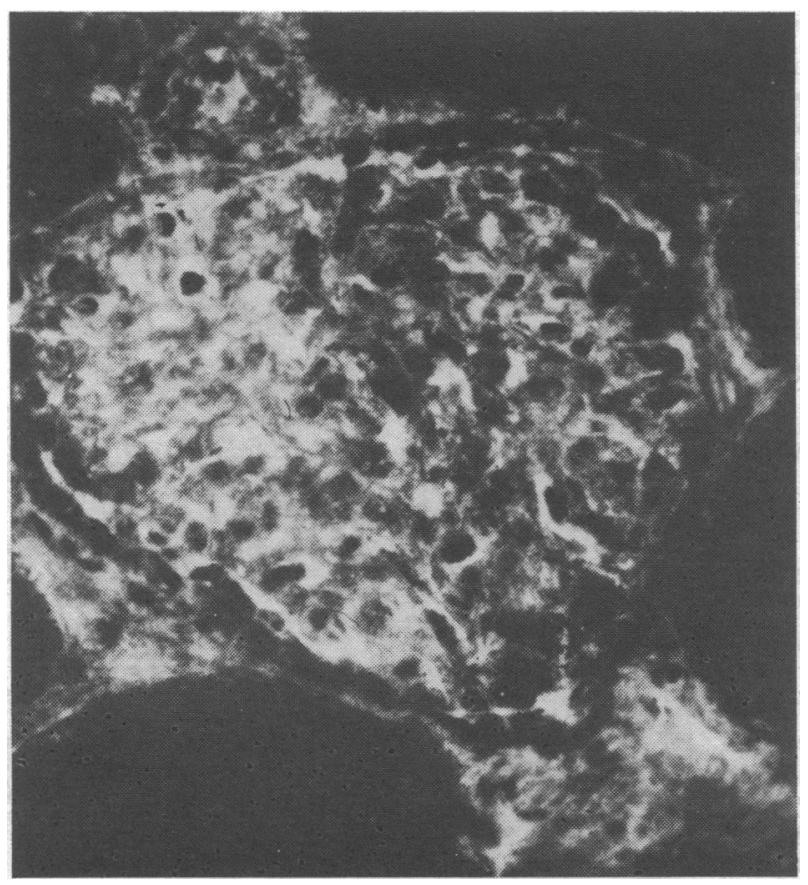
FIG. 1-Washed cryostat section of kidney showing patchy deposit of IgG in
glomerular capillaries and mesangium. (From colour transparency. $\times 940$.)

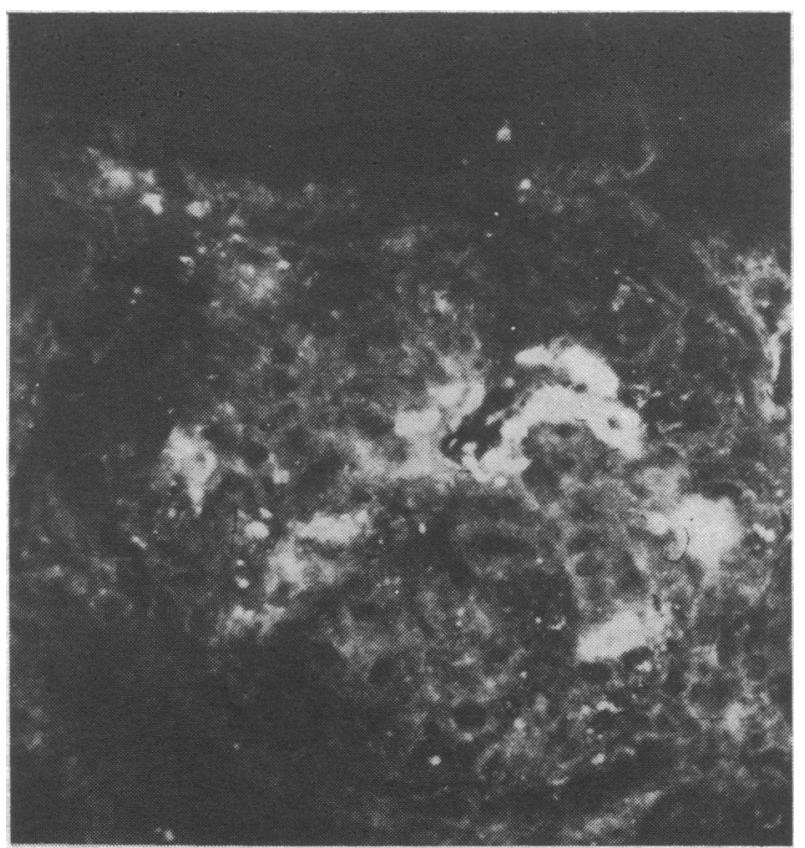

FIG. 2-Washed cryostat section of kidney showing bound complement in glomerular capillaries. (From transparency. $\times$ 940.) such cells in coeliac nodes. The spleen showed IgG-containing cells in the pulp and around Malpighian bodies and many fewer IgM-containing ones scattered throughout the red pulp.

No cryostat sections were available of the thymus. Nearby lymph nodes showed a few IgG-containing cells in the peripheral sinuses on immunofluorescent examination. Similar IgG-containing cells were found very occasionally in the sinusoids of the liver and more often in the mucosal stroma of the intestines.

\section{DISTRIBUTION OF MEASLES ANTIGEN}

Within the brain specific fluorescence of measles antigens was seen in inclusion bodies in the cytoplasm and nuclei of small numbers of neurones and glial cells.

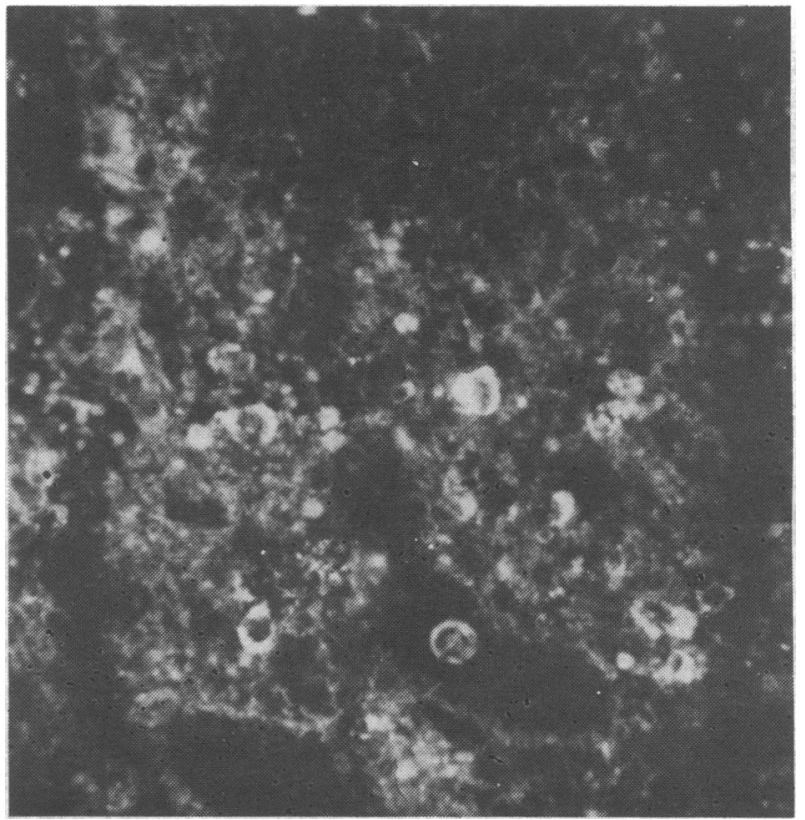

FIG. 3-Cervical lymph node. Measles antigen in cells in the cortex. (From transparency. $\times$ 940.)

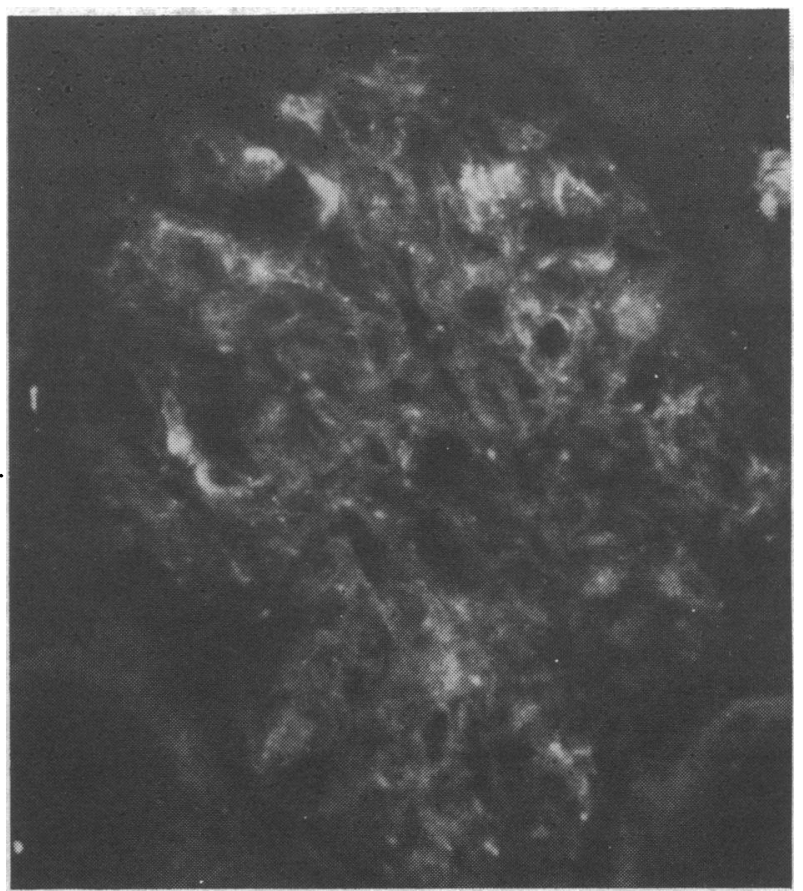

FIG. 4-Granular deposits of measles antigen in glomerular capillaries. (From transparency. $\times$ 940.) 
In washed sections of viscera measles antigens were detected by immunofluorescence in isolated cells in the peripheral sinuses and within germinal centres in the cervical (Fig. 3), axillary, and mediastinal lymph nodes. It was not found in the abdominal lymph nodes. Measles antigens were also found in small groups of cells in the splenic pulp and in sparse cells in the walls of the sinuses in the liver. No specific fluorescence was seen in cells in the lungs, stomach, or small or large intestines.

Granular deposits of measles antigens were seen in capillaries and mesangial cells in 5\% of the renal glomeruli (Fig. 4). This antigen, too, could not be removed completely by elution with acid citrate or potassium thiocyanate but the intensity of the fluorescence was diminished by treatment with these reagents.

\section{Discussion}

These findings suggest that in subacute sclerosing panencephalitis immune complexes of measles antigen and IgG are present in the circulation. They should be confirmed during life by the many other immunological and virological techniques available. The occurrence of antigenic components and even of the pathogenetic measles-like virus itself has recently been shown in lymph nodes by Fuccillo et al. (1971) and HortaBarbosa et al. (1971).

The formation of immune complexes in diverse viral infections has recently been reviewed by Oldstone and Dixon (1971) and by Notkins (1971). Even though formal study of this problem has only just begun it is striking how many chronic or temperate viral infections are associated with the appearance of immune complexes. Circulating antibody complexes may contain infectious virus (Notkins, 1971), and it is possible that this is one means by which certain viruses survive as they spread from cell to cell, as well as being enabled to reach immunologically-protected sites or to achieve the local conditions required to initiate chronic infections. Complexes deposited in tissues can produce local damage by a variety of means (Cochrane, 1971; Henson, 1971), and these processes must be considered directly in analysing the pathological effects of temperate encephalitides (Webb, 1968).

The occurrence of the measles-like virus in the reticuloendothelial system in subacute sclerosing panencephalitis is intriguing and its significance is not clear. Burnet (1968) suggested that the disease was due to an abnormal lack of reactivity of thymus-derived immunocytes against measlesinfected cells and predicted that the thymus in these patients would contain measles antigen. Unfortunately, this could not be tested because of the lack of frozen thymic tissue. The distri- bution of measles antigen observed in the present case might represent phagocytosis of immune complexes, but it seems more likely to result from a degree of immunological tolerance which had permitted widespread dissemination of the aetiological agent.

Not all strains of animals infected with potentially "temperate" viruses actually develop chronic infections (Oldstone and Dixon, 1969). The occurrence of chronicity may be due to differences in the affinity of the antibodies produced (Soothill and Steward, 1971), a factor at least partly under genetic control. It has always been difficult to explain the extreme rarity of subacute sclerosing panencephalitis if it is really due to the almost ubiquitous measles virus. If immune complexes are important in its pathogenesis, however, then perhaps only those rare individuals who make low affinity antibody are in danger of developing this disease; and only then, perhaps, if virus lodges in the thymus (Burnet, 1968) or if simultaneous infection with another virus (Dayan, 1971; Koprowski et al., 1970) occurs at a critical stage in the evolution of the disease.

We are grateful to Dr. M. J. McArdle for permission to study this patient, Dr. J. A. Dudgeon for estimating the measles antibodies, Professor K. A. Porter for advice, and Drs. A. N. Bowden and J. A. Rees for their help. We wish to thank the Peel Trust and the Cancer Research Campaign for their support.

\section{References}

Burnet, M. (1968). Lancet, 2, 610.

Cochrane, C. G. (1971). Fournal of Experimental Medicine, 134, 75s.

Connolly, J. H., Allen, I. V., Hurwitz, L. J., and Millar, J. H. D. (1968). Quarterly fournal of Medicine, 37, 625 .

Dandliker, W. B., et al. (1967). Biochemistry, 6, 1460.

Dayan, A. D. (1971). Fournal of the Neurological Sciences, 14, 315.

Freedman, P., and Markowitz, A. S. (1962). British Medical fournal, 1, 1175.

Henson, P. M. (1971). Fournal of Experimental Medicine, 134, 115s.

Horta-Barbosa, L., Fuccillo, D., Sever, J. L., Zeman, W., and Mealey, J. (1969). Nature, 221, 974 .

Horta-Barbosa, L., et al. (1971). Science, 173, 840.

Houba, V., et al. (1970). In Immune Complex Diseases, ed. L. Bonomo and J. L. Turk, p. 23. Milan, Carlo Erba Foundation.

Koprowski, H., Barbanti-Brodano, G., and Katz, M. (1970). Nature,

ter Meulen, V., Enders-Ruckle, G., Müller, D., and Joppich, G. (1969). Acta Neuropathologica, 12, 244.

Notkins, A. L. (1971). Fournal of Experimental Medicine, 134, 41s.

Notkins, A. L. (1971). Fournal of Experimental Medicine, 134, 41s.
Oldstone, M. B. A., and Dixon, F. J. (1969). Fournal of Experimental Medicine, $129,483$.

Oldstone, M. B. A., and Dixon, F. J. (1971). Fournal of Experimental Medicine, $134,32 \mathrm{~s}$.

Payne, F. E., Baublis, J. V., and Itabashi, H. H. (1969). New England fournal of Medicine, $281,585$. Sever, J. L., and Zeman, W. (1968). Neurology (Minneapolis), 18, Suppl. Soothill, J. F., and Steward, M. W. (1971). Clinical and Experimental

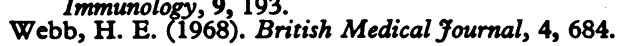

\title{
Pancreatin as a Source of Hospital-acquired Salmonellosis
}

\author{
E. J. G. GLENCROSS
}

British Medical fournal, 1972, 2, 376-378

\section{Introduction}

Summary

Two babies with fibrocystic disease of the pancreas acquired hospital infection with Salmonella agona after treatment with commercial pancreatin prepared from pig pancreas obtained from abattoirs in Britain.

The incidence of salmonellosis in apparently healthy pigs slaughtered in this country will obviously vary from time to time and place to place, but is known to increase if animals are herded together just before slaughter (McDonagh and Smith, 1958). In the symptomless carrier state in pigs salmonellae are probably restricted to the bowel and mesenteric lymph nodes (Smith, 1960), but spread to other parts of the carcass is likely during evisceration (Galton et al., 1954). Sick animals suffering from salmonella septicaemia, with consequent widespread dissemination of organisms throughout the animal, are, however, unlikely to be accepted by the abattoir. 